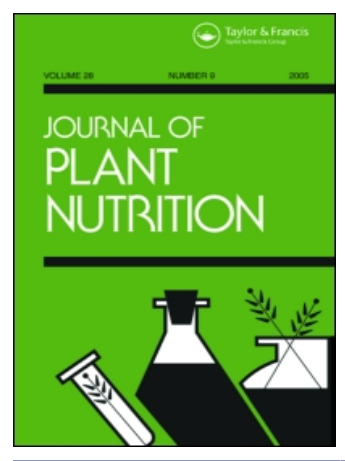

Journal of Plant Nutrition

ISSN: 0190-4167 (Print) 1532-4087 (Online) Journal homepage: https://www.tandfonline.com/loi/lpla20

\title{
Effects of nitrogen fertilization on development, flowering, and mineral nutrition of potted Costus productus Gleason ex Maas
}

Daniela Merida, Kathia Fernandes Lopes Pivetta, Renata Bachin MazziniGuedes, Carlos Eduardo Ferreira de Castro \& Luis Felipe Villani Purquerio

To cite this article: Daniela Merida, Kathia Fernandes Lopes Pivetta, Renata Bachin Mazzini-Guedes, Carlos Eduardo Ferreira de Castro \& Luis Felipe Villani Purquerio (2017) Effects of nitrogen fertilization on development, flowering, and mineral nutrition of potted Costus productus Gleason ex Maas, Journal of Plant Nutrition, 40:7, 1045-1052, DOI: 10.1080/01904167.2016.1263327

To link to this article: https://doi.org/10.1080/01904167.2016.1263327

Accepted author version posted online: 29

Dec 2016.

Published online: 18 Apr 2017.

Submit your article to this journal ¿

Џ Article views: 76

View Crossmark data ¿

Citing articles: 1 View citing articles $\sqsubset$ 


\title{
Effects of nitrogen fertilization on development, flowering, and mineral nutrition of potted Costus productus Gleason ex Maas
}

\author{
Daniela Merida ${ }^{a}$, Kathia Fernandes Lopes Pivetta ${ }^{a}$, Renata Bachin Mazzini-Guedes ${ }^{\mathrm{b}}$, \\ Carlos Eduardo Ferreira de Castro $^{c}$, and Luis Felipe Villani Purquerio ${ }^{c}$ \\ ${ }^{a}$ Department of Crop Production, College of Agricultural and Veterinary Sciences, State University of São Paulo (UNESP \\ Univ Estadual Paulista/FCAV), Jaboticabal, São Paulo, Brazil; ${ }^{b}$ Coordination of Agricultural Engineering, Advanced \\ Campus of Jandaia do Sul, Federal University of Paraná (UFPR), Jandaia do Sul, Paraná, Brazil; 'Agronomic Institute \\ (IAC), Campinas, São Paulo, Brazil
}

\begin{abstract}
Due to the lack of information on mineral nutrition of ornamental plants, especially tropical species, we aimed to evaluate the effects of nitrogen fertilization on development, flowering, and mineral nutrition of potted Costus productus. Plants were cultivated along 1 year under protection in Ubatuba, São Paulo State, Brazil, and submitted to five treatments that corresponded to increasing nitrogen doses $\left(0.0,1.2,2.4,3.6\right.$, and $4.8 \mathrm{~g} \mathrm{~N}$ plant $\left.^{-1}\right)$. Evaluated plant variables were potted development, height, dry matter of aerial part, number of inflorescences, and nutritional status. Analysis of variance and linear and polynomial regressions were performed for definition of the best adjustments according to the combination of significance and greater determination coefficient. The nitrogen fertilization positively influenced development, flowering, and mineral nutrition of potted C. productus plants, and the dose of $4.8 \mathrm{~g} \mathrm{~N}$ plant $^{-1}$ promoted best results
\end{abstract}

\section{ARTICLE HISTORY}

Received 23 April 2015

Accepted 3 February 2016

\section{KEYWORDS}

nutrition; tropical flower; ornamental plant; Costaceae; Zingiberales

\section{Introduction}

Tropical flowers have been gaining prominence and attracting attention in the flower market, especially in temperate countries. Many belong to the order Zingiberales and are perennial species with exotic flowers that have different shapes and colors, besides a generally long vase life (Costa, Espinelli, and Figueiredo 2011). Many of these flower species sold in temperate countries belong to the families Strelitziaceae (e.g., Strelitzia reginae) and Heliconiaceae (e.g., Heliconia spp.) of the order Zingiberales, although Anthurium species in the family Araceae (order Alismatales) are also commercially important and well studied.

Other tropical plants, however, could be used as cut flowers, cut foliage, garden plants, or potted plants. Species of the Costaceae (in the Zingiberales), although unusual, are now found in the flower trade, and are being marketed as potted plants for interior decoration, seedlings for gardens, or cut flowers for flower arrangements. Their spiral stems could also be used as cut foliage, promoting a very decorative effect in flower arrangements. Among these species, Costus productus Gleason ex Maas, native to Brazil and known as Orange Costus Ginger, has already been used as a garden plant, but there are also designations for other uses.

According to Castro et al. (2011), plants of C. productus usually form clumps of around 1-m height and produce 28-37 stems per plant, which is appropriate for their use as garden or potted plants since,

CONTACT Renata Bachin Mazzini-Guedes remazzini@yahoo.com.br E Federal University of Paraná (UFPR), Rua Doutor João Maximiano, 426, Vila Operária, 86900-000 Jandaia do Sul, Paraná Brazil.

Color versions of one or more of the figures in this article can be found online at www.tandfonline.com/lpla.

(c) 2017 Taylor \& Francis Group, LLC 
in these cases, good soil coverage is usually required. Its inflorescences, orange to red colored, are also used as cut flowers, as they last more than 20 days after harvest; furthermore, one plant may produce more than six inflorescences at a time, remaining blooming for more than 10 months when temperatures are maintained above $23^{\circ} \mathrm{C}$. In tropical countries, its production peak falls between August and May. Each inflorescence produces only one orange flower, which lasts 1 day and does not remain attached to the plant. In pots, plants may reach up to only $0.60-\mathrm{m}$ height, which makes it more suitable to be cultivated this way.

A rapid growth, as well as flowering, is usually desirable in floriculture, so that high rates of fertilizer may often be applied (West et al. 1980); yet, according to the same author, excessive concentrations of fertilizer may reduce growth, so information on optimum fertilizer requirements is necessary. However, recommendations for flower fertilization, in general, are still rare in Brazil. For Costus plants, for instance, fertilization has been empirically performed based on other species belonging to related families and genera. Also, it is necessary to highlight that there are no differentiated fertilization recommendations for production systems of cut flowers, garden plants, or potted plants.

Among the nutrients, nitrogen stands out for promoting morphological and physiological modifications in plants. Quantitatively, it is the most important nutrient for plant development (Malavolta 1981 ) as it is related to the most important biochemical and physiological plant processes, such as photosynthesis, respiration, and cell growth and differentiation (Carmello 1999).

In a market saturated by traditional crops, novelty is an important component of marketing strategy, so unusual species normally stimulate consumption (Siqueira 2009). In this sense, the intensification of studies and dissemination of $C$. productus ornamental characteristics will certainly contribute to market expansion. The objective of this study was to evaluate the effect of nitrogen doses on development, flowering, and mineral nutrition of Costus productus plants cultivated in pots.

\section{Materials and methods}

The experiment was conducted under protection, at Ubatuba Research and Development Unit (APTA/ UPDU), in Ubatuba, São Paulo State, Brazil $\left(23^{\circ} 26^{\prime} 13^{\prime \prime} \mathrm{S}\right.$ and $45^{\circ} 04^{\prime} 08^{\prime \prime} \mathrm{W}$, at sea level), from October 2011 to November 2012. According to the Köppen classification, the climate regime in Ubatuba is wet tropical with no dry season (Af). Annual mean rainfall is $2,500 \mathrm{~mm}$, with mean temperatures of $22.0^{\circ} \mathrm{C}, 17.4^{\circ} \mathrm{C}$ minimum, and $26.9^{\circ} \mathrm{C}$ maximum. Greenhouse dimensions, where the experiment was located, are $2.5 \mathrm{~m}$ height, $6.0 \mathrm{~m}$ width, and $35.0 \mathrm{~m}$ length, comprising $210 \mathrm{~m}^{2}$; it is arched, built with galvanized steel, and coated with anti-ultra violet (UV) low-density polyethylene of $150-\mu \mathrm{m}$ thickness; its sides were also coated with a $30 \%$ shading black net (Figure 1A). The floor was lined with raffia so that it prevented weeds from growth.

The experimental design was arranged in randomized blocks, with five treatments corresponding to increasing nitrogen doses $\left(0.0,1.2,2.4,3.6\right.$, and 4.8 g nitrogen $(\mathrm{N})$ plant $\left.^{-1}\right)$ and five blocks with 10 replications per block, totaling 250 plants.

For determination of the applied nitrogen doses, a previous study on the plant nitrogen content was performed to provide us better knowledge on C. productus nitrogen requirements. Six-month old plants, cultivated in soil, were collected at APTA/UPDU, so that macronutrient determination could be performed using both their aerial parts and rhizomes; a mean of $1.2 \mathrm{~g} \mathrm{~N}$ plant $^{-1}$ was found.

For the experiment, plants were cultivated along 1 year (Figure $1 \mathrm{~B}$ and $\mathrm{C}$ ). Therefore, considering the nitrogen amount of $1.2 \mathrm{~g} \mathrm{~N}$ in a 6-month old plant and the 12-month cultivation cycle in the experiment, the dose of $2.4 \mathrm{~g} \mathrm{~N}$ was adopted as the standard in this study, with the exception of the control plants that did not receive any nitrogen application. The other doses were then applied as follows: the dose of $1.2 \mathrm{~g} \mathrm{~N}$ is $50 \%$ of the standard dose of $2.4 \mathrm{~g}$, and the doses of 3.6 and $4.8 \mathrm{~g} \mathrm{~N}$, in turn, are $150 \%$ and $200 \%$ of the standard dose.

Seedlings were obtained from stem cuttings of 0.30 -m length harvested from vigorous adult plants cultivated at APTA/UPDU. Cuttings rooted in a greenhouse coated with a $70 \%$ shading black net, and there was no additional treatment for rooting. Seedlings were then transplanted to 14-L polyethylene pots filled with a substrate equally composed of peat, pine bark, and vermiculite. Phosphorus and 

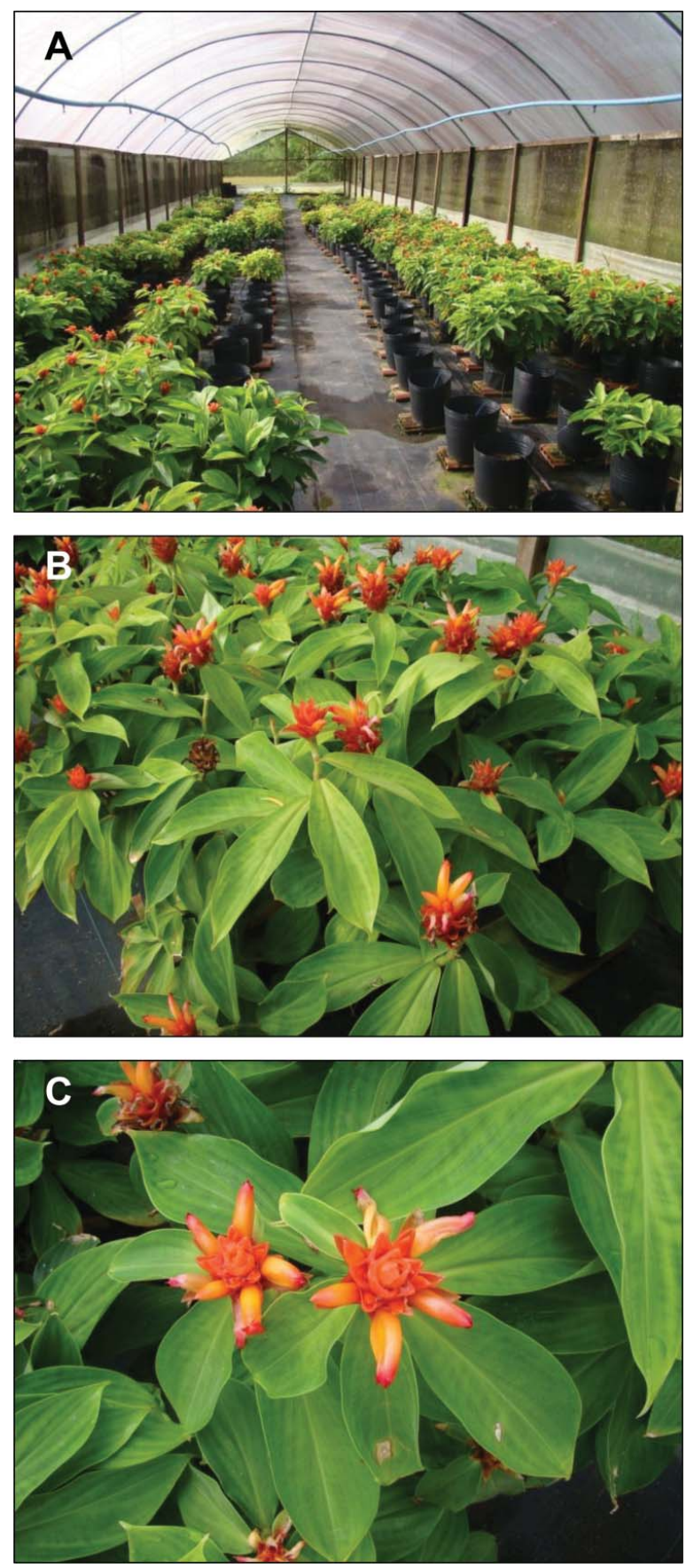

Figure 1. A) Greenhouse used for the experiment, in Ubatuba, São Paulo State, Brazil; B) Costus productus plants after 12-month cultivation and C) Costus productus inflorescences (C).

potassium were also added to the substrate in the proportion of $60 \%$ and $30 \%$ of the substrate amount; these macronutrients were previously determined according to the macronutrient analysis.

Because of lack of recommendations for C. productus, fertilization was estimated according to the plant nutrient uptake, as verified in that previous study. Phosphorus was then transformed to phosphorus pentoxide $\left(\mathrm{P}_{2} \mathrm{O}_{5}\right)$ (by multiplying by 2.29), and potassium to potassium oxide $\left(\mathrm{K}_{2} \mathrm{O}\right)$ (by multiplying by 1.20 ), considering an efficiency of $40 \%$ for phosphorus $(\mathrm{P}), 80 \%$ for potassium $(\mathrm{K})$, and $50 \%$ for 
calcium (Ca) and magnesium (Mg). The amount of applied $\mathrm{P}_{2} \mathrm{O}_{5}, \mathrm{~K}_{2} \mathrm{O}$, Ca, and $\mathrm{Mg}$ was 2.4, 4.0, 1.5, and $2.0 \mathrm{~g}$ plant $^{-1}$, respectively. Supply of $\mathrm{P}, \mathrm{Ca}, \mathrm{Mg}$, and micronutrients was performed using the thermal phosphate magnesium fertilizer, with micronutrient addition, that presented $17 \% \mathrm{P}_{2} \mathrm{O}_{5}, 18 \% \mathrm{Ca}$, $7 \% \mathrm{Mg}, 0.10 \%$ boron $(\mathrm{B}), 0.05 \%$ copper $(\mathrm{Cu}), 0.15 \%$ manganese $(\mathrm{Mn})$, and $0.55 \%$ zinc $(\mathrm{Zn})$. Posterior fertigations were also performed, with combinations of monoammonium phosphate (MAP-44\% $\left.\mathrm{P}_{2} \mathrm{O}_{5}\right)$, potassium chloride $\left(58 \% \mathrm{~K}_{2} \mathrm{O}\right)$, and potassium and magnesium sulfate $\left(26 \% \mathrm{~K}_{2} \mathrm{O}, 10 \% \mathrm{Mg}\right.$, and $15 \% \mathrm{~S})$.

The supplied nitrogen fertilizer was ammonium nitrate $(32 \% \mathrm{~N})$, which was applied as follows: $10 \%$ soon after planting; $10 \%$ every month along the first 6 months; and 5\% every month, from the 7 th to the 12th month. Topdressing was manually performed for each pot with the water-dissolved fertilizer. For water supply, a drip irrigation system was used, with one dripper for each pot that released $70 \mathrm{~mL} /$ day.

At 12 months of growth, the following variables were evaluated: potted plant development, evaluated according to substrate surface coverage by the plant, and classified into four groups: up to 25\%; from $26 \%$ to $50 \%$; from $51 \%$ to $75 \%$; above $75 \%$ surface coverage; plant height (cm), measured from the substrate surface up to the apex of the highest inflorescence, with the help of a ruler; dry matter of aerial part $(\mathrm{g})$, determined after plant drying in an air-forced circulation heater at $60^{\circ} \mathrm{C}$; and nutritional status, via determination of $\mathrm{N}, \mathrm{P}, \mathrm{K}, \mathrm{Ca}, \mathrm{Mg}$, sulfur $(\mathrm{S}), \mathrm{B}, \mathrm{Cu}$, iron $(\mathrm{Fe}), \mathrm{Mn}$, and $\mathrm{Zn}$ contents in the plant aerial part according to the method described by Malavolta, Vitti, and Oliveira (1997). Total number of inflorescences was also evaluated along 3 months, that is, from flowering beginning (September 2012) up to the final evaluation (November 2012).

Data were statistically analyzed via variance analysis; when significant, analyses of linear and polynomial regressions were also performed to define best adjustments according to the combination of significance and highest determination coefficient. Data of number of inflorescences were transformed to $(x+1)^{1 / 2}$ only for statistical analysis.

\section{Results and discussion}

There were no significant differences for potted plant development since, for the majority of the individuals, substrate coverage was above $75 \%$. However, there was a significant effect of the nitrogen doses on the other development and flowering characteristics, i.e., plant height, dry matter of aerial part, and number of inflorescences, with adjustments of positive linear regressions for all of them according to the increasing nitrogen doses (Figure 2).

Inflorescence number also increased with the increment in nitrogen doses (Figure 2). Plants produced a mean of 20.8 inflorescences, maximum, when cultivated under the highest tested dose ( $4.8 \mathrm{~g} \mathrm{~N}$ plant $\left.^{-1}\right)$. When submitted to nitrogen deficiency $\left(0 \mathrm{~g} \mathrm{plant}^{-1}\right)$, plants produced a mean of 13.4 inflorescences.

Nitrogen deficiency, therefore, negatively affected height of C. productus plants (Figure 2), as it also happened to Curcuma alismatifolia (in the family Zingiberaceae of the order Zingiberales), another tropical plant that presented decreased height and number of stems and leaves per cluster when cultivated under the lowest tested dose $\left(50 \mathrm{mg} \mathrm{N} \mathrm{L}^{-1}\right.$ ) (Ruamrungsri et al. 2005). Also, Smith, Elliott, and Bridgen (1998) reported poor growth of flower stems of Alstroemerias cultivated under no nitrogen or low doses $\left(3.5 \mathrm{mmol} \mathrm{N} \mathrm{L}{ }^{-1}\right)$. On the contrary, Heliconia psittacorum x H. spathocircinata "Golden Torch," also a tropical flower belonging to the order Zingiberales, was not influenced, at least in height, by nitrogen absence (Castro et al. 2007). These different experimental results evidence the need for more specific studies on tropical plant nutrition, as each species seems to have its own nutritional requirements. Furthermore, knowledge on plant nutritional requirements is essential to ensure good yields and avoid nutrient waste (Dufour and Guérin 2005), which could contribute to soil salinization and impracticability.

Reductions in the plant aerial part due to nitrogen absence is also reported for other ornamentals, such as Spathiphyllum sp. (Alismatales) (Yeh, Lin, and Wright. 2000), Helianthus annuus (Asterales) (Cechin and Fumis 2004), and Heliconia psittacorum x H. spathocircinata "Golden Torch" (Castro 

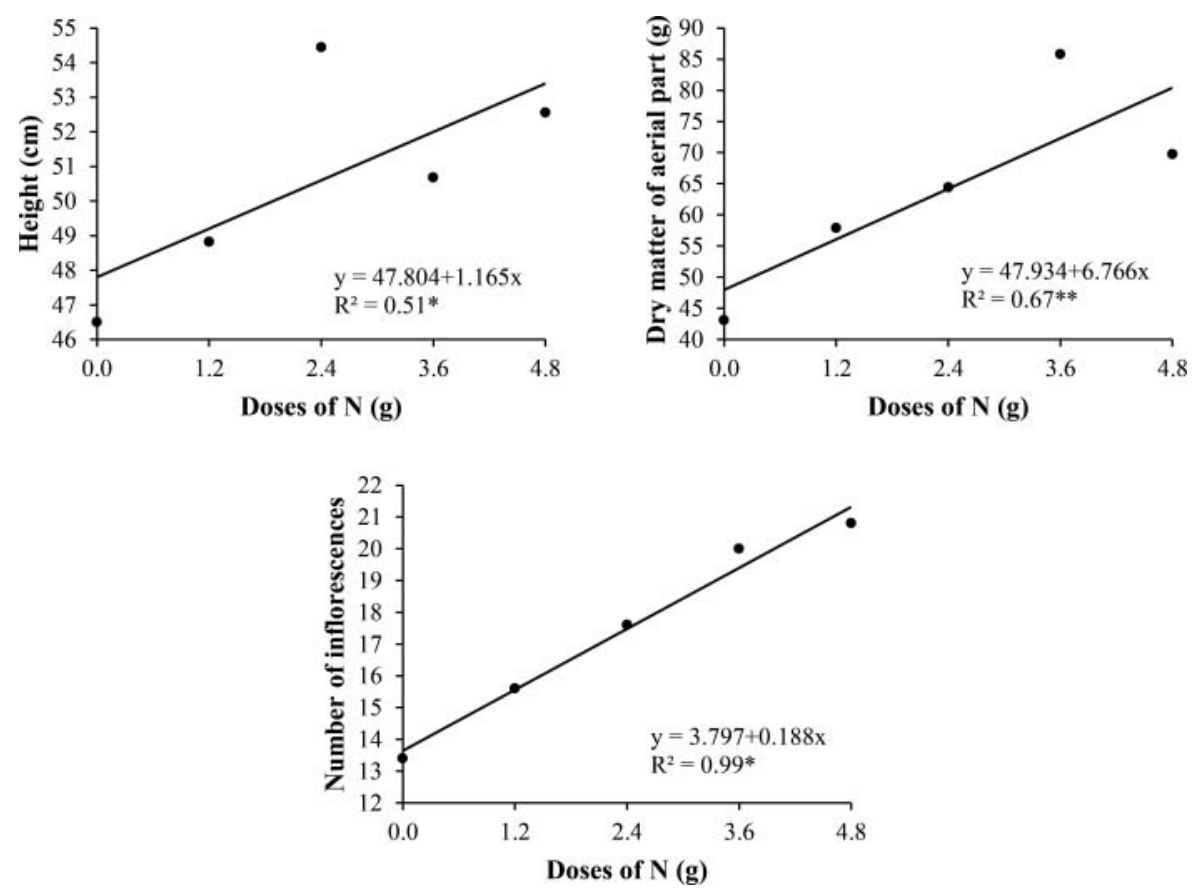

Figure 2. Variations of height, dry matter of aerial part, and number of inflorescences of Costus productus at 12 months after planting according to doses of nitrogen (N). ${ }^{* *}$ Significant at $p \leq 0.01$; *Significant at $p \leq 0.05(n=250)$. Polynomial regressions were not significant for all variables.

et al. 2007). Furthermore, Castro et al. (2007) observed that nitrogen was the most influencing nutrient on stem dry matter accumulation of H. psittacorum x H. spathocircinata "Golden Torch," resulting in $67 \%$ reduction when comparing with other plants cultivated under complete fertilization with macronutrients and micronutrients. On the other hand, Camargo, Mello, and Carmello (2008) verified that the dry matter of Aster ericoides (Asterales) aerial part was not influenced by nitrogen fertilization.

Regarding the inflorescence number, the difference between the lowest $\left(0 \mathrm{~g} \mathrm{plant}^{-1}\right)$ and highest nitrogen dose ( $4.8 \mathrm{~g} \mathrm{~N}$ plant $^{-1}$ ) was 7.4 inflorescences (from 20.8 to 13.4 inflorescences, respectively); therefore, considering that the commercialization classification criteria is usually based on, among others, inflorescence number, the producer must aim at maximum number to achieve the highest market price.

Other studies on ornamentals have also shown the influence of nitrogen fertilization on flower production. Arora and Saini (1976), when studying the effect of nitrogen doses (0, 200, 300, and $400 \mathrm{~kg}$ $\mathrm{ha}^{-1}$ ) on aster plants cultivated in sandy loam soil previously fertilized with $5 \mathrm{~kg} \mathrm{ha}^{-1}$ cattle manure and $120 \mathrm{~kg} \mathrm{ha}^{-1} \mathrm{~K}_{2} \mathrm{O}$, observed higher number of flowers from plants submitted to $200 \mathrm{~kg} \mathrm{~N} \mathrm{ha}{ }^{-1}$. Similarly, Maheswar (1978) observed positive nitrogen effects on the same species cultivated under the highest tested dose $\left(180 \mathrm{~kg} \mathrm{~N} \mathrm{ha}^{-1}\right)$, describing greater production. Vijayakumar, Patil, and Hulmaniet (1988), when studying the effect of plant density and nitrogen doses $\left(180,240\right.$, and $\left.340 \mathrm{~kg} \mathrm{ha}^{-1}\right)$ on chrysanthemum cultivation, observed greater production when $300 \mathrm{~kg} \mathrm{~N} \mathrm{ha}^{-1}$ was applied.

Furthermore, nitrogen is indirectly related to flowering beginning and duration. According to Ruamrungsri et al. (2005), optimum nitrogen supply is involved in stimulating earlier occurrence of vegetative tissue formation in Curcuma alismatifolia, so when leaves are well developed, flower bud initiation subsequently occurs. Similarly, Dufour and Guérin (2005) found longer Anthurium vegetative stage in plants cultivated under the lowest tested nitrogen dose $\left(4.5 \mathrm{mmol} \mathrm{N} \mathrm{L}^{-1}\right)$, which resulted in flowering delay. For a specialized grower, flowering delay means financial losses, as more agricultural inputs and manpower will be necessary up for the achievement of commercialization standards. Also, according to Marschner (1995), time or form of application is more important than nitrogen level, and 
effects of nutrient supply on flower formation derive from changes in phytohormone levels, thus resulting in the indirect effect on flowering.

Effects of general fertilization on flower production seem to be species-related, as Cuquel et al. (2012) found similar Anthurium flower production from, also, 1-year plants cultivated under different fertilization levels. Our results showed, however, that C. productus plants did respond to nitrogen fertilization already during its first year of cultivation, presenting higher means under $4.8 \mathrm{~g} \mathrm{~N} \mathrm{plant}^{-1}$. Also, Lee, Lee, and Suh (2008) found flowering delay for Curcuma thorelli "Chiang Mai Snow" but not for C. alismatifolia "Chiang Mai Pink" under the same nitrogen dose of $6.6 \mathrm{~g} \mathrm{~L}^{-1}$, which confirms different responses from distinct species. The authors also had fewer inflorescences from both species under that same dose, reaching a higher number when C. alismatifolia plants were submitted to $2.7 \mathrm{~g} \mathrm{~N} \mathrm{~L}^{-1}$, and C. thorelli from 1.3 to $4.0 \mathrm{~g} \mathrm{~N} \mathrm{~L}^{-1}$, some of the lowest tested doses.

Nitrogen fertilization also significantly affected N, P, B, and Fe contents in the plant aerial part, with adjustments of positive linear regressions for all these nutrients according to the increasing nitrogen doses (Figure 3). There were no significant effects for $\mathrm{K}, \mathrm{Ca}, \mathrm{Mg}, \mathrm{S}, \mathrm{Cu}, \mathrm{Mn}$, and $\mathrm{Zn}$ contents.

According to Marschner (1995), the increase in phosphorus contents due to nitrogen application may occur because of greater phosphorus absorption and transportation in the plant; since the ammonium raises the dissociation rate of the phosphate-carrier complex in the xylem, phosphorus concentrations in the aerial part also increases.

Similarly, Lopes (1996) and Natale et al. (2006), when studying nitrogen effects on Passiflora sp. (in the family Passifloraceae of the order Malpighiales) plants, verified that the increment in nitrogen doses also raised N, P, Fe, and $\mathrm{Zn}$ contents in the aerial part. Furthermore, Natale et al. (2006) also achieved nitrogen positive effects on S and Ca contents, while Camargo, Mello, and Carmello (2008) found that further nitrogen fertilization increased its own content in Aster ericoides stems, even when cultivated in highly fertile soil. Also, Smith, Elliott, and Bridgen (1998) and Lee, Lee, and Suh (2008) found an increase in $\mathrm{N}$ contents in leaves of Alstroemeria flower stems and Curcuma spp., respectively, with $\mathrm{N}$ supply.
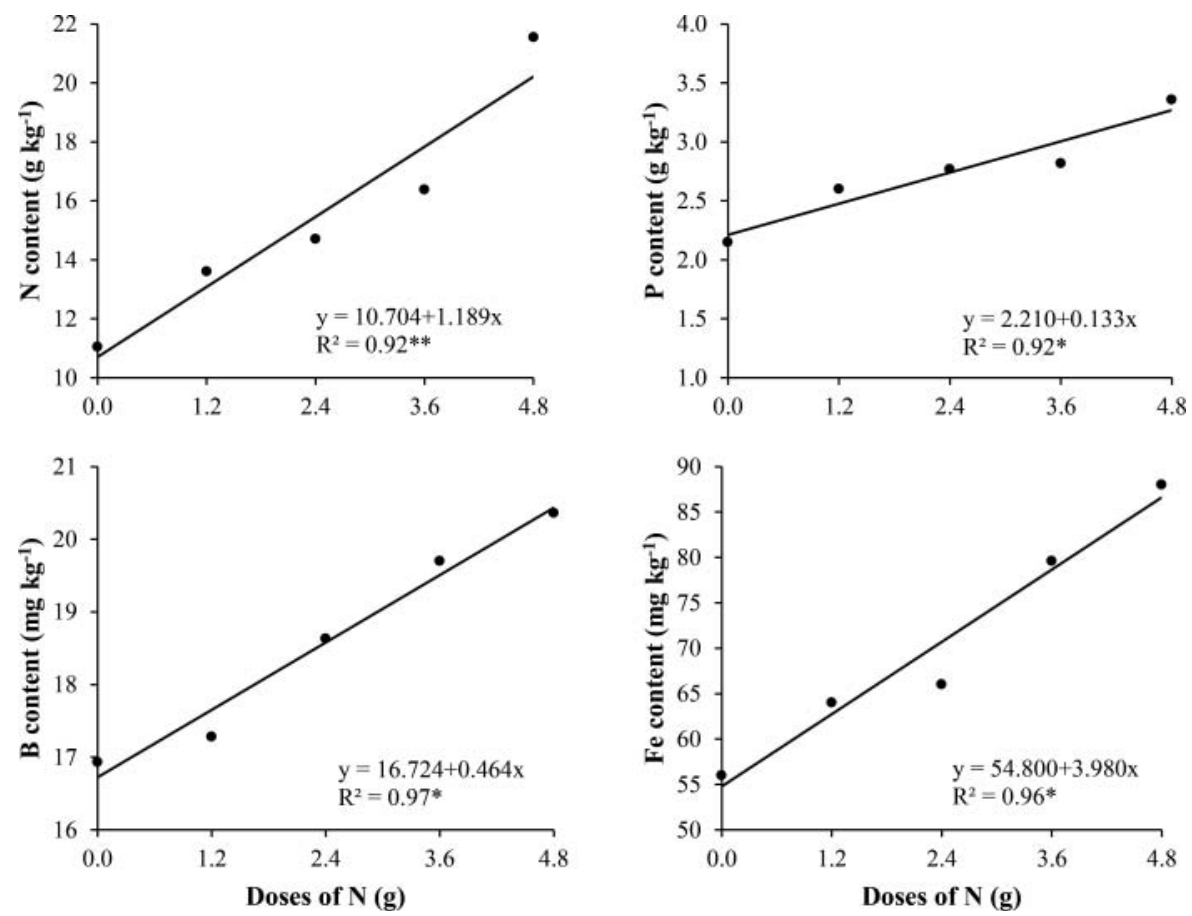

Figure 3. Variations of nitrogen $(\mathrm{N})$, phosphorus $(\mathrm{P})$, boron $(\mathrm{B})$, and iron $(\mathrm{Fe})$ contents in the aerial part of Costus productus plants according to doses of nitrogen $(\mathrm{N})$. **Significant at $\mathrm{p} \leq 0.01$; ${ }^{*}$ Significant at $\mathrm{p} \leq 0.05(\mathrm{n}=250)$. Polynomial regressions were not significant for all variables. 
The significant effect of nitrogen fertilization on increased B and Fe contents observed in this study (Figure 3) may be due to the use of physiologically acidic fertilizers that contain nitrogen as $\mathrm{NH}_{2}-\mathrm{N}_{\text {or }}$ ammonium $\left(\mathrm{NH}_{4}{ }^{+}-\mathrm{N}\right)$, as well as nitrate $\left(\mathrm{NO}_{3}-\mathrm{N}\right)$, which should reduce soil $\mathrm{pH}$ more than if potassium nitrate were supplied and so increase nitrogen availability to plants. That could consequently enhance micronutrient absorption (Malavolta and Neptune 1983), although the rhizosphere pH effects may directly affect availability of B and Fe.

\section{Conclusion}

The nitrogen fertilization positively influenced development, flowering, and mineral nutrition of Costus productus plants cultivated in pots. The dose of $4.8 \mathrm{~g} \mathrm{~N}$ plant $^{-1}$ promoted greater development, which was verified by highest means of height, dry matter of aerial part, and flower production. The same dose was also responsible for increasing N, P, B, and Fe contents in the plant aerial part. However, as plants were only evaluated along their first year of growth, further studies are necessary to define optimum annual nitrogen fertilization along their life cycle, always aiming at improved flower production.

\section{Funding}

The authors thank São Paulo Research Foundation (FAPESP/Process number 11/04138-1) for granting a Masters bursary to the first author.

\section{References}

Arora, J. S., and S. S. Saini. 1976. A note on the effect of different levels of nitrogen and plant densities on the flower production in Aster (Callistephus chinensis). Haryana Journal of Horticultural Sciences 5: 96-97.

Camargo, M. S., S. C. Mello, and Q. A. C. Carmello. 2008. Nitrogen and potassium fertilization of Aster ericoides cultivated in greenhouse. Horticultura Brasileira 26 (2): 190-193.

Carmello, Q. A. C. 1999. Course on Nutrition/Fertigation in Localized Irrigation. Piracicaba, Brazil: ESALQ/Departamento de Solos e Nutrição de Plantas.

Castro, A. C. R., V. Loges, A. S. Costa, M. F. A. Castro, F. A. Z. Aragão, and L. G. Willadino. 2007. Flower stems postharvest characteristics of heliconia under macronutrients deficiency. Pesquisa Agropecuária Brasileira 42 (9): $1299-1306$.

Castro, C. E. F., S. R. Moreira, A. C. R. Castro, F. V. D. Souza, V. Loges, C. Gonçalves, M. A. P. C. Costa, and L. F. Moura. 2011. Evaluation of Costaceae species for ornamental use. Revista Brasileira de Horticultura Ornamental 17 (1): $63-$ 74.

Cechin, I., and T. F. Fumis. 2004. Effect of nitrogen supply on growth and photosynthesis of sunflower plants grown in the greenhouse. Plant Science 166 (5): 1379-1385.

Costa, F. R. C., F. P. Espinelli, and F. O. G. Figueiredo. 2011. Guide to the Zingiberales of PPBio Sites in Brazilian Western Amazonia. Manaus, Brazil: Áttema Design Editorial.

Cuquel, F. L., S. W. Polack, N. Favaretto, and J. C. Possamai. 2012. Fertigation and growing media for production of anthurium cut flower. Horticultura Brasileira 30 (2): 279-285.

Dufour, L., and V. Guérin. 2005. Nutrient solution effects on the development and yield of Anthurium andreanum Lind. in tropical soilless conditions. Scientia Horticulturae 105 (2): 269-282.

Lee, J. S., A. K. Lee, and J. K. Suh. 2008. Optimum nutrient level on growth, flowering, and rhizome production in curcuma. Journal of Plant Nutrition 31 (12): 2183-2195.

Lopes, P. S. N. 1996. Sexual Propagation of Passiflora edulis Sims. f. flavicarpa Deg.: Effect of Nitrogen Fertilization and Substrate. Lavras, Brazil: Federal University of Lavras, MS Dissertation.

Maheswar, D. L. 1978. Influence of nitrogen and phosphorus on growth and flower production of China aster (Callistephus chinensis Nees). Mysore Journal of Agricultural Sciences 12: 528-532.

Malavolta, E. 1981. Components of Plant Nutrition. São Paulo, Brazil: Agronômica Ceres.

Malavolta, E., and A. M. L. Neptune. 1983. Characteristics and Efficiency of Nitrogen Fertilizers. São Paulo, Brazil: SN Centro de Pesquisa e Promoção de Sulfato de Amônio.

Malavolta, E., G. C. Vitti, and S. A. Oliveira. 1997. Evaluation of Plant Nutritional Status: Principles and Applications. Piracicaba, Brazil: Potafos.

Marschner, H. 1995. Mineral Nutrition of Higher Plants. New York, USA: Academic Press.

Natale, W., R. M. Prado, E. V. Almeida, and J. C. Barbosa. 2006. Nitrogenous and potassic fertilization on nutritional status of yellow passion fruit seedlings. Acta Scientiarum. Agronomy 28 (2): 187-192. 
Ruamrungsri, S., C. Suwanthada, P. Apavatjrut, N. Ohtake, K. Sueyoshi, and T. Ohyama. 2005. Effect of nitrogen and potassium on growth and development of Curcuma alismatifolia Gagnep. Acta Horticulturae 673: 443-448.

Siqueira, C. V. A. 2009. Crown-of-Thorns (Euphorbia milii Des Moulins) as Potted-Plant, MS Dissertation, Agronomic Institute, Campinas, Brazil.

Smith, M. A., G. C. Elliott, and M. P. Bridgen. 1998. Calcium and nitrogen fertilization of Alstroemeria for cut flower production. HortScience 33 (1): 55-59.

Vijayakumar, K. T., A. A. Patil, and N. C. Hulmaniet. 1988. Effect of plant density and nitrogen on growth characters and flower yield of China aster (Callistephus chinensis Nees) cv. Ostrich Plume Mixed. South Indian Horticulture 36: 318-320.

West, D. W., I. F. Merrigan, J. A. Taylor, and G. M. Collins. 1980. Growth of ornamental plants irrigated with nutrient or polyethylene glycol solutions of different osmotic potentials. Plant and Soil 56 (1): 99-111.

Yeh, D. M., L. Lin, and C. J. Wright. 2000. Effects of mineral nutrient deficiencies on leaf development, visual symptoms and shoot root ratio of Spathiphyllum. Scientia Horticulturae 86 (3): 223-233. 